\title{
PERBEDAAN KOMITMEN ORGANISASI DITINJAU DARI GENDER KARYAWAN PT. INDOMARCO PRISMATA MEDAN
}

\author{
Putri Ayu Rizki dan Rahmi Lubis \\ Universitas Medan Area
}

\begin{abstract}
ABSTRAK
Penelitian ini bertujuan untuk melihat perbedaan komitmen organisasi ditinjau dari gender pada karyawan PT.Indomarco Prismatama Medan. Kami mengajukan hipotesis bahwa komitmen organisasi perempuan akan cenderung lebih tinggi daripada laki-laki. Partisipan dalam penelitian ini berjumlah 40 orang karyawan (20 laki-laki, 20 perempuan) yang bekerja di PT.Indomarco Prismatama Medan. Hasil menunjukkan bahwa komitmen organisasi para karyawan secara umum adalah tinggi. Namun, sesuai dengan hipotesis yang kami ajukan, komitmen organisasi perempuan lebih tinggi daripada laki-laki.
\end{abstract}

Kata-kata kunci: Komitmen organisasi, gender

\section{GENDER DIFFERENCES IN ORGANIZATIONAL COMMITMENT AMONG EMPLOYEES OF PT. INDOMARCO PRISMATA MEDAN}

\begin{abstract}
The present study was aimed to examine differences in organizational commitment between gender among PT. Indomarco Prismatama Medan employee. We hypothesized that female employees would tend to have higher organizational commitment compared to the male employees. Participants were 40 employees (20 males, 20 females) who works in PT. Indomarco Prismatama Medan. The results show that organizational commitment were higher among the female in comparison to the male employees.
\end{abstract}

Keywords: Organizational commitment, gender

Komitmen seseorang terhadap organisasi atau perusahaan menjadi isu yang sangat penting dalam dunia kerja. Komitmen merupakan konsep manajemen yang menempatkan sumber daya manusia sebagai figur sentral dalam organisasi usaha, tanpa komitmen sukar diharapkan partisipasi aktif dan mendalam dari sumber daya manusia yang ada dalam perusahaan. Begitu pentingnya hal tersebut, hingga beberapa organisasi mensyaratkan unsur komitmen sebagai salah satu persyaratan untuk memegang suatu jabatan atau posisi yang ditawarkan dalam iklan-iklan lowongan pekerjaan. Sayangnya meskipun hal ini sudah sangat umum, tidak jarang pengusaha maupun karyawan masih belum memahami arti komitmen secara sungguhsungguh. Padahal pemahaman tersebut sangat penting agar tercipta kondisi kerja yang kondusif sehingga perusahaan dapat berjalan secara efektif dan efisien (dalam Sit umorang, 2009).

*Korespondensi mengenai penelitian ini dapat dilayangkan kepada Rahmi Lubis melalui email: makmunrahmi@yahoo.com
Steers (dalam Situmorang, 2009) mendefinisikan komitmen organisasi sebagai rasa identifikasi (kepercayaan terhadap nilai-nilai organisasi), keterlibatan (kesediaan untuk berusaha sebaik mungkin demi kepentingan organisasi) dan loyalitas (keinginan untuk tetap menjadi anggota organisasi yang bersangkutan) yang dinyatakan oleh seorang pegawai terhadap organisasinya. Steers lebih lanjut berpendapat bahwa komitmen organisasi merupakan kondisi di mana karyawan sangat tertarik terhadap tujuan, nilai-nilai, dan sasaran organisasinya. Komitmen terhadap organisasi artinya lebih dari sekedar keanggotaan formal, karena meliputi sikap menyukai organisasi dan kesediaan untuk mengusahakan tingkat upaya yang tinggi bagi kepentingan organisasi. Kondisi tersebut tercermin dari hasil penelitian dari Baron dan Greenberg (dalam Situmorang, 2009), menyatakan bahwa komitmen memiliki arti penerimaan yang kuat dalam

Rekomendasi mensitasi:

Rizki, A. P., \& Lubis, R. (2013). Perbedaan komitmen organisasi ditinjau dari gender karyawan PT. Indo Prismata Medan. Psikologia, 8(1), 19-24. 
diri individu terhadap tujuan dan nilai-nilai perusahaan, sehingga individu tersebut akan berusaha dan berkarya serta memiliki hasrat yang kuat untuk tetap bertahan di perusahaan tersebut.

Steers (dalam Situmorang, 2009) mendefinisikan komitmen organisasi sebagai rasa identifikasi (kepercayaan terhadap nilai-nilai organisasi), keterlibatan (kesediaan untuk berusaha sebaik mungkin demi kepentingan organisasi) dan loyalitas (keinginan untuk tetap menjadi anggota organisasi yang bersangkutan) yang dinyatakan oleh seorang pegawai terhadap organisasinya. Steers lebih lanjut berpendapat bahwa komitmen organisasi merupakan kondisi di mana karyawan sangat tertarik terhadap tujuan, nilai-nilai, dan sasaran organisasinya. Komitmen terhadap organisasi artinya lebih dari sekedar keanggotaan formal, karena meliputi sikap menyukai organisasi dan kesediaan untuk mengusahakan tingkat upaya yang tinggi bagi kepentingan organisasi. Kondisi tersebut tercermin dari hasil penelitian dari Baron dan Greenberg (dalam Situmorang, 2009), menyatakan bahwa komitmen memiliki arti penerimaan yang kuat dalam diri individu terhadap tujuan dan nilai-nilai perusahaan, sehingga individu tersebut akan berusaha dan berkarya serta memiliki hasrat yang kuat untuk tetap bertahan di perusahaan tersebut.

Menurut Porter, (dalam Kreitner \& Kinicki, 2002) adanya komitmen organisasi yang tinggi pada karyawan akan membuat karyawan terhindar dari perilaku-perilaku keorganisasian yang negatif. Misalnya; membolos, mangkir, pindah kerja ke perusahaan lain, meninggalkan jam kerja, dan lain sebagainya. Inilah yang manjadi dasar pengharapan berbagai perusahaan agar para karyawannya mempunyai komitmen yang tinggi. Selain itu, dengan komitmen yang tinggi, karyawan juga akan cenderung bersedia untuk mengerahkan usaha yang cukup atas nama organisasi, dan memiliki keinginan yang kuat untuk menjaga agar dirinya terus menjadi bagian dari organisasi.

Sayangnya, kenyataan yang terjadi di lapangan tidak selalu ideal. Tidak semua karyawan mempunyai komitmen yang tinggi. Rendahnya komitmen mencerminkan kurangnya tanggung jawab seseorang dalam menjalankan tugasnya. Karyawan yang memiliki komitmen yang rendah akan memiliki semangat yang rendah dalam bekerja dan berkarya, cepat lelah, bosan, emosi tidak stabil serta memiliki tingkat absensi yang tinggi.

Dalam era globalisasi yang penuh dengan persaingan, peran seseorang tidak lagi banyak mengacu kepada norma-norma kebiasaan yang lebih banyak mempertimbangkan faktor gender, akan tetapi ditentukan oleh daya saing dan keterampilan. Laki-laki dan perempuan sama-sama berpeluang untuk memperoleh kesempatan dalam persaingan. Sebagai bukti nyata bahwa perempuan punya peluang yang sama dengan laki-laki dalam persaingan. Ini dapat dilihat dengan semakin meningkatnya jumlah perempuan di dunia kerja, baik di perusahaan swasta maupun dalam instansi pemerintahan. Melihat perempuan yang bekerja dalam perusahaan, sebagaimana terjadi di PT. Indomarco Prismatama Medan bukanlah sebuah fenomena yang asing lagi dewasa ini. Namun, peningkatan itu tidak mampu merobohkan dominasi laki-laki dalam dunia kerja, karena peran perempuan dalam berkarir seringkali terbentur dengan dinding budaya.

Meskipun demikian, masuknya perempuan di dunia kerja pada saat ini menunjukkan jumlah yang semakin besar dan menjadi hal menarik untuk diteliti. Hal ini menjadi menarik mengingat situasi yang dialami perempuan dalam dunia kerjanya yang penuh dengan tekanan. Seperti jam kerja yang tinggi, besarnya kuantitas kerja yang diharapkan, adanya deadline klien, level kerja yang berat, pengendalian dan pengawasan yang ketat, level kompetisi yang tinggi, dan tantangan budaya. Hal tersebut di atas juga terjadi di 
PT. Indomarco Prismatama Medan. Perbedaan gender menyebabkan karyawan yang mengeluh dengan beban tugas yang dikerjakan, dan ada karyawan yang tidak menyelesaikan tugas sesuai dengan standar yang telah ditentukan karena karyawan tidak memiliki kemampuan, dengan demikian sangat diperlukan komitmen untuk meningkatkan kinerja dan produksivitas kerja sesuai yang diinginkan oleh perusahaan.

\section{Perbedaan komitmen organisasi ditinjau dari gender}

Sebagian besar para peneliti psikologi industri dan organisasi setuju bahwa komitmen organisasi yang kuat berasal dari interaksi variabel demografi individual (misalnya usia dan jenis kelamin), variabel psikologi pribadi (misalnya kebutuhan dan nilai-nilai), dan karakteristik keadaan kerja tertentu (misalnya., sifat kerja, dalam Jewell \& Siegall, 1998). Dari banyak variabel yang dihipotesiskan menjadi penentu komitmen organisasi, mungkin salah satu variabel yang paling banyak disebutkan adalah sistem nilai pribadi seseorang. Menurut Chusmir, (dalam Jewell \& Siegall, 1998), ada tiga kelompok yang mempengaruhi komitmen Organisasi yaitu pribadi, eksternal atau situasional dan perseptual. Variabel individual dan situasional mempunyai pengaruh langsung pada komitmen organisasi dan menghasilkan persepsi individu terhadap diri sendiri dengan mengacu pada pekerjaan dan jabatan.

Selanjutnya, Chusmir (dalam Jewll \& Siegall, 1998) berpendapat bahwa faktor gender mempunyai kaitan konseptual dengan komitmen organisasi dan pengaruhnya terutama kuat sekali pada perempuan, karena mereka adalah sumber pertentangan peran gender yang jarang dialami laki-laki yang bekerja. Bagi perempuan, tantangan terbesar adalah mengintegrasikan antara peran dalam keluarga dengan peran dalam pekerjaan atau karir.
Dalam penelitian yang dilakukan oleh Liyod Lueptow, (dalam Santrock, 2008), perempuan memiliki tingkat yang tinggi dalam orientasi berprestasi daripada lakilaki. Yang mana, perempuan adalah peraih sukses yang ulet, sedangkam laki-laki adalah pesaing yang ulet. Namun, banyak peneliti yang mengabaikan perbedaan ini, orientasi berprestasi perempuan sering dianggap remeh. Begitu banyak perempuan lebih disosialisasikan dengan peran mengurus keluarga dibanding dengan peran yang berhubungan dengan berkarir atau berprestasi, mereka secara tradisional tidak merencanakan karir dengan serius, tidak mengeksplorasi pilihan karir secara mendalam dan terpaku pada pilihan karir yang terstereotipe secara gender. Komitmen organisasi sebenanya setara bagi kedua jenis kelamin. Namun, laki-laki dan perempuan mempunyai pilihan karir yang berbeda karena pengalaman sosialisasi mereka dan kekuatan sosial dalam masyarakat yang menentukan kesempatan yang tersedia bagi mereka (Asrin, dalam Santrock, 2008). Lebih lanjut Cherington (1994) menyatakan bahwa karyawan perempuan sebenarnya justru cenderung lebih berkomitmen terhadap organisasi dibandingkan dengan karyawan laki-laki.

\section{METODE}

\section{Partisipan}

Populasi dalam penelitian ini adalah karyawan PT. Indomarco Prismatama Medan, dengan jumlah populasi sebanyak 72 orang. Dari populasi tersebut, sebanyak 40 orang (20 laki-laki, 20 perempuan) karyawan berusia antara 18 sampai 40 tahun berpartisipasi di dalam penelitian ini.

\section{Alat ukur}

Alat ukur dalam penelitian ini adalah skala Komitmen Organisasi yang kami buat berdasarkan aspek-aspek komitmen organisasi yang diutarakan oleh Allen dan Meyer (1997). Skala kami buat dengan 
respon jawaban empat titik ( $1=$ "Sangat tidak setuju", 2 = "Tidak setuju", $3=$ "Setuju", 4 = "Sangat setuju"). Skala ini pada awalnya terdiri atas 30 aitem yang cukup reliabel $(\alpha=.842)$. Namun, dari 30 aitem tersebut, tujuh aitem kami keluarkan dari analisis, karena memiliki kemampuan diskriminasi yang rendah. Pada akhirnya, jumlah aitem yang terlibat dalam analisis lanjutan adalah sebanyak 23 aitem.

\section{HASIL}

\section{Deskriptif}

Secara umum, Komitment Organisasi karyawan PT. Indomarco Prismatama Medan dapat dilihat pada Tabel 1. Dalam upaya mengetahui kondisi Komitmen Organisasi, maka perlu dibandingkan antara rerata empirik dengan mean/nilai rata-rata hipotetik dengan memperhatikan besarnya bilangan standar deviasi $(S D)$ dari variabel yang sedang diukur. Nilai SD variabel Komitmen Organisasi adalah sebesar 7.13. Apabila rerata hipotetik lebih kecil daripada rerata empirik, dimana selisihnya melebihi bilangan satu $S D$, maka para partisipan penelitian memiliki Komitmen Organisasi yang tinggi. Apabila rerata hipotetik lebih besar daripada rerata empirik, dimana selisihnya melebihi bilangan satu $S D$, maka para partisipan memiliki Komitmen Organisasi yang rendah. Selanjutnya apabila rerata empirik tidak berbeda (tidak melebihi bilangan $S D$ ) dengan rerata hipotetiknya, maka Komitmen Organisasi karyawan dinyatakan sedang.

Tabel 1 Deskripsi komitmen organisasi

\section{Komitmen organisasi berdasarkan gender}

Kami berhipotesis bahwa perempuan akan memiliki komitmen organisasi yang lebih tinggi dibanding laki-laki. Hipotesis ini kami uji dengan melakukan one way anova. Hasil menunjukkan terdapat perbedaan Komitmen Organisasi yang signfikan antara laki-laki dan perempuan, $F(1,38)=13.70, p=.001 . \quad$ Sesuai dengan hipotesis yang diajukan, perempuan memiliki skor Komitment Organisasi yang lebih tinggi daripada lakilaki (lihat Tabel 1 untuk rerata laki-laki dan perempuan).

\section{DISKUSI}

Di dalam penelitian ini kami membandingkan komitmen organisasi antara karyawan laki-laki dan perempuan PT. Indomarco Prismatama Medan. Hasil yang didapatkan menunjukkan adanya perbedaan tingkat komitmen organisasi yang signifikan antara laki-laki dan perempuan. Sesuai dengan hipotesis yang diajukan, meskipun secara umum para karyawan memiliki komitmen organisasi yang tinggi, tidak dapat dipungkiri bahwa karyawan perempuan memiliki komitmen organisasi lebih tinggi dibanding karyawan laki-laki.

Hasil penelitian ini sejalan dengan pendapat sebelumnya yang dikemukakan oleh Liyod Lueptow (dalam Santrock, 2008) bahwa perempuan memiliki tingkat yang tinggi dalam orientasi berprestasi daripada laki-laki. Yang mana, perempuan adalah peraih sukses yang ulet, sedangkan laki-laki adalah pesaing yang ulet. Lebih-

\begin{tabular}{|c|c|c|c|c|}
\hline \multirow[b]{2}{*}{ Variabel } & \multicolumn{2}{|c|}{ Rerata } & \multirow[b]{2}{*}{$S D$} & \multirow[b]{2}{*}{ Keterangan } \\
\hline & Hipotetik & Empirik & & \\
\hline Komitmen Organisasi & 57.50 & 76.22 & 7,13 & Komitmen tinggi \\
\hline $\begin{array}{l}\text { Komitmen Organisasi } \\
\text { Perempuan }\end{array}$ & 57.50 & 79.58 & 5.31 & $\begin{array}{l}\text { Komitmen Organisasi } \\
\text { Tinggi }\end{array}$ \\
\hline $\begin{array}{l}\text { Komitmen Organisasi } \\
\text { Laki-laki }\end{array}$ & 57.50 & 72.69 & 6.96 & $\begin{array}{l}\text { Komitmen Organisasi } \\
\text { Tinggi }\end{array}$ \\
\hline
\end{tabular}


lanjut Cherington (1994) menyatakan bahwa karyawan perempuan cenderung lebih berkomitmen terhadap organisasi dibandingkan dengan karyawan laki-laki.

Menurut Chusmir, (dalam Jewell \& Siegall, 1998), ada tiga variabel model yang mempengaruhi komitmen Organisasi yaitu pribadi atau individual, eksternal atau situasional dan perseptual. Variabel individual dan situasional mempunyai pengaruh langsung pada komitmen Organisasi dan menghasilkan persepsi individu terhadap diri sendiri dengan mengacu pada pekerjaan dan jabatan. Semua variabel model Chusmir, telah ditemukan berkorelasi dengan komitmen organisasi dalam penelitian terdahulu, tetapi jenis kelamin merupakan model formal pertama yang memasukkan faktor di luar lingkungan kerja (karakteristik keluarga).

Chusmir (dalam Jewel \& Siegall, 1998), berpendapat bahwa faktor gender mempunyai kaitan konseptual dengan komitmen organisasi dan pengaruhnya terutama kuat sekali pada perempuan karena mereka adalah sumber pertentangan peran gender yang jarang dialami laki-laki yang bekerja, perempuan berharap untuk bisa berhasil mengintegrasikan antara peran dalam keluarga dengan peran dalam pekerjaan atau karir. Begitu banyak perempuan lebih disosialisasikan dengan peran mengurus keluarga dibanding dengan peran yang berhubungan dengan berkarir atau berprestasi, mereka secara tradisional tidak merencanakan karir dengan serius, tidak mengeksplorasi pilihan karir secara mendalam dan terpaku pada pilihan karir yang terstereotipe secara gender. Komitmen organisasi sebenarnya setara bagi kedua gender. Namun, laki-laki dan perempuan mempunyai pilihan karir yang berbeda karena pengalaman sosialisasi mereka dan kekuatan sosial dalam masyarakat yang menentukan kesempatan yang tersedia bagi mereka (Asrin, dalam Santrock, 2008).

\section{Saran}

Sebagai penutup, beberapa saran yang dapat diajukan berdasarkan penelitian ini adalah sebagai berikut:

\section{Saran untuk karyawan}

Komitmen Organisasi merupakan suatu kondisi psikologis yang penting dimiliki oleh setiap karyawan. Penelitian ini menunjukkan bahwa komitmen organisasi karyawan PT. Indomarco Prismatama Medan tergolong tinggi. Dengan demikian, perlu disarankan kepada para karyawan untuk mempertahankan komitmen organisasi tersebut. Hal ini sangat penting, karena dengan dimilikinya komitmen organisasi yang tinggi, perusahaan dapat survive (bertahan lama) dan karyawan mendapat keuntungan dari keberhasilan perusahaan tersebut serta dapat mencapai tingkat jabatan yang lebih tinggi.

\section{Saran untuk perusahaan}

Pihak Perusahaan, khususnya untuk personalia, disarankan bahwa hasil penelitian ini dapat dipergunakan untuk menentukan kriteria karyawan yang diprediksikan akan sukses sebagai karyawan. Disamping itu, organisasi dapat melihat bagaimana komitmen organisasi pada program-program yang disusun seperti memberikan pelatihan dan pembinaan pengembangan karyawan dan pengembangan organisasidalam usahanya untuk berbenah diri menuju ketaraf yang lebih baik lagi.

\section{Saran untuk penelitian selanjutnya}

Untuk peneliti selanjutnya yang berminat untuk mengangkat tema yang sama, diharapkan dari hasil penelitian ini nantinya dapat memberi gambaran bahwasanya ada beberapa faktor lain seperti usia, masa kerja, dan pendidikan yang mempengaruhi komitmen organisasi. Faktor-faktor tersebut perlu menjadi perhatian para peneliti selanjutnya. 


\section{REFERENSI}

Allen, N. J., \& Meyer, J. P. (1997). Commitment in the workplace: Theory, research and application. Sage Publication

Cherrington, D. J. (1994). Organizational behavior: The management of individual and organizational performance. Simon of Schulter inc.

Jewell, L. N. \& Siegall, M. (1998). Psikologi industri/organisasi modern: Psikologi terapan untuk memecahkan berbagai masalah di tempat kerja, perusahaan, industri dan organisasi (edisi 2). Jakarta: Arcan.

Kreitner, R dan Kinicki, A. (2002). Perilaku Organisasi 1 (Edisi 5). Jakarta: Penerbitan Salemba Empat.

Santrock, J. W. (2008). Educational psychology (edisi 2). Jakarta: Kencana.

Situmorang, D. (2009). Hubungan antara Kepuasan Kerja dengan Komitmen Organisasi perawat di RS Pirngadi Medan.

Skripsi.(Tidak

Diterbitkan).Perpustakaan Universitas Medan Area. 